\title{
Characteristics of local inflammation of the fibula bone material from Tell Masaikh (Syria)*
}

\section{Charakterystyka miejscowego stanu zapalnego kości strzałkowej z materiału kostnego ze stanowiska w Syrii}

\author{
Hanna Mańkowska-Pliszka ${ }^{1,2}$, Jacek Tomczyk ${ }^{3}$ \\ ${ }^{1}$ Department of Clinical and Anatomy Study, Medical University of Warsaw, Poland \\ ${ }^{2}$ Department of Vertebrate Morphology, Siedlce University of Natural Sciences and Humanities, Poland \\ ${ }^{3}$ Institute of Ecology and Bioethics, Cardinal Stefan Wyszyński University in Warsaw, Poland \\ ORCID: HM-P https://orcid.org/0000-0003-1237-1418; JT https://orcid.org/0000-0002-0605-665X• j.tomczyk@uksw.edu.pl
}

\begin{abstract}
Inflammatory states usually precede the development of an organ or systemic pathologies. Whether a given infection that causes such a state has a chance to develop, depends on many individual and environmental factors. Post-inflammatory changes can be traced in the osseous material. Therefore, macroscopic, radiological and histological analysis was performed on the upper epiphysis of the right fibula (caput fibulae) with a lesion within the articular surface turned towards the tibia (facies articularis capitis fibulae). The research material came from the excavations led in Tell Masaikh (Syria).
\end{abstract}

Keywords: palaeopathology, ostitis, Tell Masaikh

Streszczenie: Stany zapalne zwykle poprzedzają rozwój ogólnoustrojowych zmian. To, czy dana infekcja wywołująca taki stan ma szansę się rozwinąć, zależy od wielu czynników indywidualnych i środowiskowych. W materiale kostnym można prześledzić zmiany pozapalne. W związku z tym wykonano analizę makroskopową, radiologiczną i histologiczną górnej nasady kości strzałkowej prawej (caput fibulae) oraz zmianą w obrębie powierzchni stawowej skierowaną w stronę kości piszczelowej (facies articularis capitis fibulae). Materiał badawczy pochodził z wykopalisk prowadzonych w Tell Masaikh (Syria).

Słowa kluczowe: paleopatologia, ostitis, Tell Masaikh

\section{Introduction}

Inflammation is the starting point for later extensive pathological changes. Their scope is usually wider and they are linked with consequences in the form of circulatory disorders, which is also associated with increased permeability of blood vessels, resulting in swelling of surrounding tissues. Later on, proliferation takes place, i.e. reconstruction of the affected area in the form of a scar or bone deformation. There can be numerous causes of inflammation. We divide them into exogenous (extrinsic) and endogenous (intrinsic) causes. The first ones are caused by viruses, bacteria, fungi and their toxins. Usually, mechanical trauma opens the way to infection (Jakubowski 1969, 615; Buri 1979,

" This article was originally published in Polish as Mańkowska-Pliszka, Hanna, and Jacek Tomczyk. 2011. "Charakterystyka miejscowego stanu zapalnego kości strzałkowej z materiału kostnego ze stanowiska w Syrii." Studia Ecologiae et Bioethicae 9(4): 37-45. The translation of the article into English was financed by the Ministry of Science and Higher Education of the Republic of Poland as part of the activities promoting science - Decision No. 676/P-DUN/2019 of 2 April 2019. Translation made by GROY Translations. 
130). Endogenous pathological factors are induced by already existing diseases (Groniowski and Kruś 1991, 280). These factors cause systemic and organ changes, for instance the occurrence of functional and building block disorders of the muscular system may result in the appearance of abscesses, which, in turn, can re-infect bone (Wegner and Alavi 1991, 401).

Osteoarthritis may coexist with inflammation of the periosteum (periostitis), bone marrow (myelitis) or, as in the examined case, the bone tissue itself (osteitis). The main causes of inflammation are microorganisms that enter the bones after an injury (Jakubowski 1969, 615; Bielewski et al. 2007, 136; Aufdereide and Rodríguez-Martín $2008,172)$. This happens more often when an open fracture occurs, or sometimes it may be sufficient to break the integrity of the shell and a lack of asepsis. Poor immune and ischemic conditions of the pathologically changed area also contribute to the development of the infection. The most common microorganism responsible for bone inflammation is Staphylococcus aureus (Spodaryk 1996, 219; Ortner 2003, 181; Waldron 2009, 84). In hospital patients, the infection can be confirmed by microbiological or histological examination. As these are highly invasive tests (particularly biopsy), alternative methods are being sought to classify bone inflammation and its causes (Goebel et al. $2007,859)$. In the case of bone material, the identification of the disease entity is difficult due to the fact that a prolonged bone infection may only be a prelude to degenerative pathological changes covering not only the cortical part of the bone but also the spongy part, causing disorders in the bone marrow function and further consequences (Morrisy and Shore 1989). Therefore, in paleopathological analyses, attention should be paid not only to the type of disease entity, but also the stage of the disease in the examined individual.

\section{Material and methods}

For over 14 years a French-Syrian archaeological expedition led by Prof. Maria Grazia Masetti-Rouault (Ecole Pratique des Hautes
Etudes, Paris) works in the Middle Euphrates Valley in Tell Masaikh (Syria). The site is located on the left bank of the Euphrates, about $6 \mathrm{~km}$ from ancient Terqa $\left(34^{\circ} 58^{\prime} 23^{\prime \prime} \mathrm{N}\right.$ $\left.40^{\circ} 33^{\prime} 13^{\prime \prime} \mathrm{E}\right)$. The excavations at Tell Masaikh were initially of a rescue nature, but over time they have developed into regular excavations (Fig. 1). Systematic anthropological research in the Middle Euphrates Valley began in 2002. The Tell Masaikh site includes mainly remains from the Neo-Assyrian period - in King Assurnasiral II's inscription (883-859 BC.) the city was described as Kar-Assurnasirpal (or Assurnasirpal's Quay). It flourished in the 8th century BC. when the palace of the Assyrian royal official, Nergaleresh, governor of the province of Rasappa was built (Roux 1992, 24; Masetti-Rouault 2002, 570; 2010, 134-136; Herles 2007, 429).

After Mesopotamia was occupied by the Arabs in the 7th century, the Middle Euphrates Valley was quite densely populated and the area enjoyed economic stability. It was only in the 13th century that the Mongols invasion caused an almost complete annihilation of the local settled population. Tell Masaikh hasn't had significant traces of settlement since the 12th/13th century, and an Islamic cemetery was established in this place, functioning to this day.

During the 2010 excavation season, a highly incomplete skeleton of an adult was found (the bones of the lower limb were preserved in fragments) with the catalogue number MK 15H13. The archaeo-

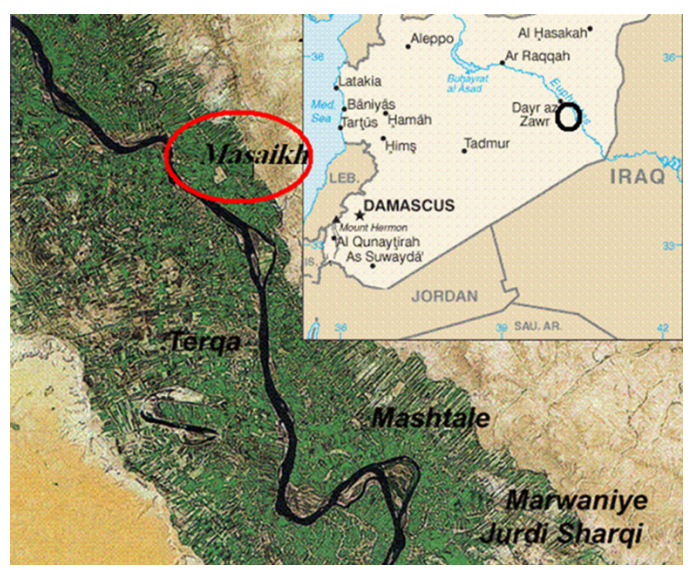

Fig. 1. The area of the Middle Euphrates Valley with the marked archaeological site. 
logical record indicates that the individual came from the Islamic period, i.e. between 600 and $1200 \mathrm{CE}$. The fragmentary nature of the material made it impossible to assess the sex. The age of the individual has been identified as adultus (Tomczyk 2011). Nevertheless, attention was drawn to the upper epiphysis of the right fibula (caput fibulae) with a pathological lesion in the area of the articular surface facing the tibia (facies articularis capitis fibulae).

To determine the disease entity, our analyses were carried out from the morphological, histological and radiological angle. The interesting bone fragment was transported for specialist radiological (X-ray) and histological examinations. The qualitative, macroscopic analysis was carried out using the Optika SZM-1 binocular equipped with a $45^{\circ}$ full - rotation binocular head, with $12 \mathrm{~V} / 15 \mathrm{~W}$ halogen illuminators for reflected and transmitted light. X-rays were performed using a Flexavision Shimadzu apparatus with HF generator and $1 \mathrm{mpx}$ CCD camera. All images were taken in the anterior-posterior plane, with an exposure time of 1.2s. Histological preparations were also made to identify the disease entity. The preparations were prepared from a section of the fibula from the affected area. The material for the histological preparation was taken at a height of $3 \mathrm{~mm}$ from the bone edge. The preparation was first dehydrated in 50-99.8\% alcohol, then in ethanol-xylene blending, and finally in pure xylene. Bone decalcification lasted for 3 days in a $4 \%$ neutral buffered formalin solution. The sample was then washed with tap water for 30 minutes and then immersed in an $8 \% \mathrm{HCl}$ solution. After complete decalcification, the samples were rinsed with water and briefly transferred to an ammonia solution to neutralize the acid for another $30 \mathrm{~min}$ utes. Paraffin deposition was performed at $52^{\circ} \mathrm{C}$ for 12 hours. The material was cut using a SLEE CUT 4055 microtomes with double-concave knives. In this way slices of $5 \mu \mathrm{m}$ thick were obtained. The dewaxing was performed twice in xylene and then the material was hydrated in EtOH starting with absolute alcohol and ending with $70 \%$ alcohol. The prepared sample was placed in water and then in dyes $(\mathrm{H}+\mathrm{E})$. Once again, the material was dehydrated and then treated with xylene and resin (Entellan). The histological sample was observed using the BX41M Olympus microscope.

\section{Results}

In the macroscopic image, the analysed fragment of the epiphysis is characterized by a large $(26 \times 6 \mathrm{~mm})$ bone niche that covers the surface facing the tibia (facies articularis capitis fibulae). The interior of the niche is woven from a single bone, as are the walls themselves, although these do not show a large thickening. The edges of the created niche are sharp. On surfaces around the niche, a non - significant reconstruction of the broken layer is observed. Also, the visible marrow cavity shows no abnormalities, its weaving is normal (Photo. 1).

The X-ray image shows the correct weave of the bone bars. However, in the niche itself, as well as in its vicinity, a slight calcification with a speckled-band structure with delimited, irregularly structured deposits with slight points of thinning of

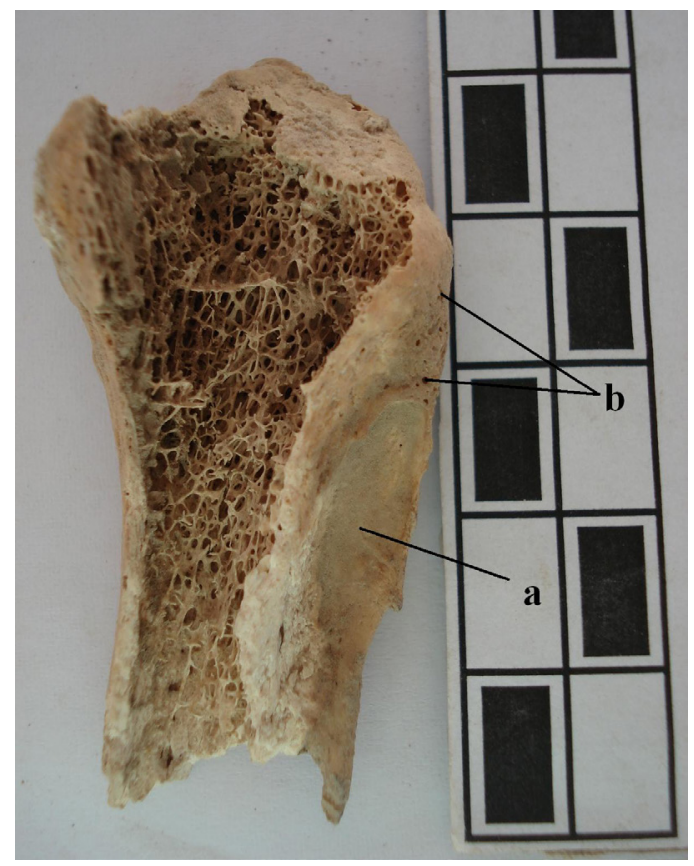

Photo. 1. The joint surface of the bonehead: a - pointed edges, b - bone reconstruction. 


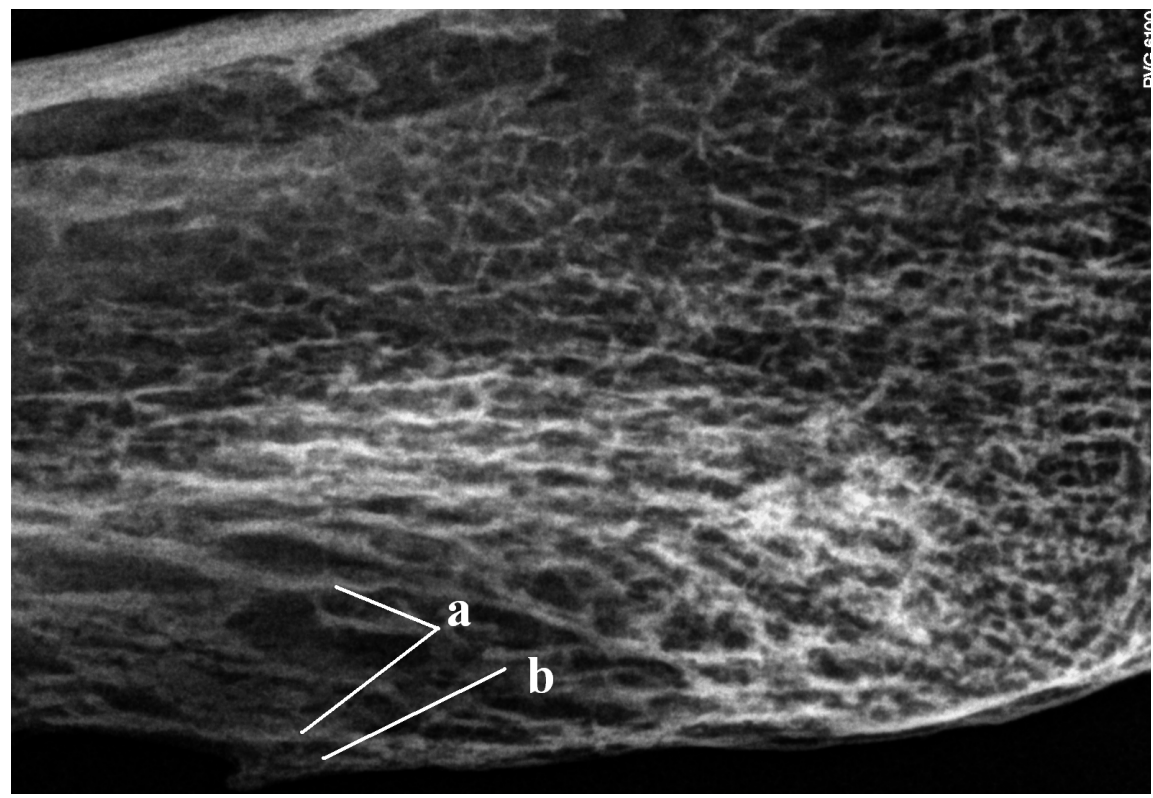

Photo. 2. X-ray image of the proximal epiphysis: a - irregular deposits, b - sclerotic lesions.

the cortical layer is visible. The periphery of the lesion has a clear outline indicating the sclerotic processes (calcium saturation) characteristic of the healing processes (Photo. 2).

The histological image shows a lack of bone structure cohesion that is in the process of volume increase reconstruction. The Haversian canals mostly have a correct structure, but those located closer to the bone niche are characterized by an irregular structure and slight enlargement. This picture suggests that the bone is slightly inflamed or, more likely, is undergoing an initial phase towards bone and marrow inflammation. The lack of necroses confirms this hypothesis (Photo. 3).

\section{Discussion}

Macroscopic examinations and tests carried out (X-ray, histological) indicate that we are dealing with an external infection, i.e. post-traumatic. This is primarily because the lesions only affect one bone. In the case of endogenous inflammation, the disease usually involves several bones. Similarly, in the case of blood-borne infections, their foci in the bones are usually very small, but quite specific and visible in the histological picture, which was not found in our material. The pathological lesion is located near the epiphysis, which is typical of inflammation in adults, who usually suffer from ischemic disorders (poor blood circulation in the capillaries). In children, similar lesions are most often found in the metaphysis sections. In this case, bone resorption (ostitis rarefaciens) occurred as a result of the inflammatory process, and therefore the medial surface of the bone, i.e. the surface adjacent to the tibia, deepened. Subsequently, the tangential edge was built up with the edge

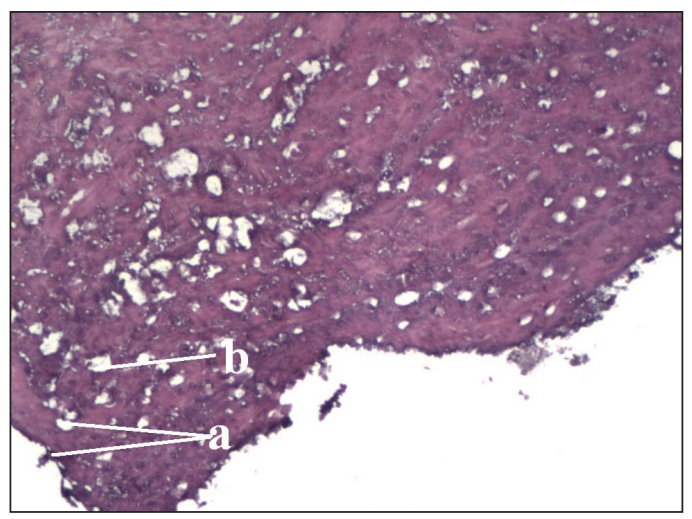

Photo. 3. Histological picture of the medial edge and surrounding tissue: $a$ - scarred edge of the lesion (cortical layer), b - remodelling lesions (core layer). 
sharpening and its hardening (o.ossificans), which proves the healing processes.

By analysing local inflammation, it can be concluded that it initially included the cortical structure of the bone. The root cause of the infection was probably injury with disruption of the skin and soft tissues. The infection itself was limited to the infection site, as evidenced by the healed edges of the bone cavity. However, above the niche and in the lateral plane, slight lesions are visible covering the spinal (marrow) part, which makes it possible to develop the disease towards osteomyelitis. At the time of death, the test subject was probably in the transition phase between the extinction of bone inflammation, as evidenced by healing, but at the same time, the general condition of the system allowed the infection to move to the interior of the bone.

Acknowledgements: Research funded with a grant from the Ministry of Science and Higher Education for 2009-2011 (No. N N303 319837).

\section{Bibliography}

Aufderheide, Arthur C., and Conrado Rodríguez-Martín. 2008. The Cambridge encyclopedia of human paleopathology. Cambridge: Cambridge University Press.

Bielawski, Janusz, Jan Sygnatowicz, and Małgorzata Olszewska-Konarska. 2007. Zapalenie kości. Warszawa: PZWL.

Burri, Caius. 1979. Posttraumatische Osteitis. Bern-Stuttgart-Toronto: Verlag Huber.

Goebel, M., F. Rosa, K. Tatsch, A. Grillhoesl, G.O. Hofmann, and M.H. Kirschner. 2007. "Diagnosis of chronic osteitis of the bones in the extremities. Relative value of F-18 FDGPET." Unfallchirurg 110: 859-66. https://doi. org/10.1007/s00113-007-1302-y.

Groniewski, Janusz, and Stefan Kruś. 1991. Podstawy patomorfologii. Warszawa: PZWL.
Herles, Michael. 2007. "Assyrische Präsenz an Euphrat und Balīh." Ugarit-Forschungen 39: 413-449.

Jakubowski Sylwester. 1969. „Zapalenie kości, szpiku i okostnej." W Choroby narzadu ruchu, red. Włodzimierz Brühl, 615-622, Warszawa: PZWL.

Masetti-Rouault, Maria-Grazia. 2002. "Rapporto Preliminare Sui Lavori Della Missione NelSito di Tell MasaikhNel 2001." Estratto da Athenaeum. Studi di Letteratura e Storiadell'Antichità 90: 570-581.

Masetti-Rouault, Maria-Grazia. 2010. "Rural Economy and Steppe Management in an Assyrian Colony in the West: a View from tell Masaikh Lower Middle Euphrates, Syria." Studia Chaburensia 1: 129-150.

Morrisy, Raymond, and Steven L. Shore. 1989. Acute hematogenous osteomyelitis. Orthopaedic infection. Diagnosis and treatment. Philadelphia: W.B. Saunders Company.

Ortner, Donald J. 2003. Identification of pathological conditions in human skeletal remains. London: Academic Press.

Roux, Georges. 1992. Ancient Iraq. London: Penguin Book.

Spadaryk, Krzysztof. 1996. Zarys fizjologii $i$ patofizjologii układu ruchu człowieka. Kraków: Wydawnictwo AZ.

Tomczyk, Jacek. 2011. "Preliminary report on human remains from Tell Masaikh and Tell Ashara. Season 2010." AkhPurattim 4.

Waldron, Tony. 2009. Paleopathlogy. Cambridge: Cambridge University Press.

Wegener, William, and Abass Alavi. 1991. "Diagnostic imaging of musculosceletal infection, Roentgenography; Gallium, Indium-labeled white blood cells, gamma globulin, bone scintigraphy and MRI." Orthopedic Clinics of North America 22: 401-418. 